\title{
CRIMINAL POLICY IN THE SHIPMENT OF FOREIGN FISHERMAN SHIPS IN THE PERSPECTIVE OF ECONOMIC ANALYSIS
}

\author{
Sri Dwi Retno Ningsih \\ Sebelas Maret University \\ sridwiretnoningsihlimbong@gmail.com \\ Adi Sulistyono \\ Sebelas Maret University \\ adisulistiyono@staff.uns.ac.id
}

\begin{abstract}
The theft of fish resources in the Indonesian sea has caused huge losses to the fisheries sector in order to realize the welfare of the community. The Ministry of Maritime Affairs and Fisheries adopted a strict policy to eradicate illegal fishing through the act of sinking illegal fishing vessels. The magnitude of Indonesia's marine and fisheries wealth cannot be utilized optimally. Law enforcement is very important to deal with violations of law in Indonesian waters. One form of law enforcement is to implement policies such as sinking foreign vessels that steal fish in Indonesian waters while taking into account the efficiency and effect of deterrent effect on perpetrators of fish theft. The sinking policy of foreign fish-stealing vessels in Indonesian waters was pursued to secure the sea from looting by foreign parties. This policy will continue even though it could risk creating friction with the countries of origin of the foreign ship. Based on economic analysts on illegal fishing crimes, criminal fines can be used as an alternative to criminal punishment in addition to imprisonment in order to minimize operational costs of law enforcement.
\end{abstract}

Keywords: Criminal Policy, Economic Analysis, Sinking of foreign ships.

\section{A. INTRODUCTION}

Indonesia is one country that has two geographical forms of a country, namely the islands and the mainland. Indonesia is one of the countries with the largest and most islands in the world, consisting of 17,508 islands with a coastline of $81,000 \mathrm{~km}$ and territorial waters of around 3.1 million $\mathrm{km} 2$. With this vast area, Indonesia has a lot of natural wealth. A number of entrepreneurs are still seen to manage Indonesia's natural wealth in earnest, which only aims solely for mere economic gain. Utilization of natural resources sometimes uses methods that do not or damage the surrounding natural environment. ${ }^{1}$

In Indonesia, there are many illegal economic problems, but one of the most detrimental to the country is the problem of Illegal, Unregulated, and Unreported Fishing (IUU Fishing) practices by foreign vessels. Criminal fishing or better known as Illegal, Unreported and Unregulated (IUU fishing) can be categorized into three groups: (1) Illegal fishing is illegal fishing activities in the territorial waters or EEZ of a country, or does not have a permit from that country;

1 Supramono, Hukum Acara Pidana dan Hukum Pidana di Bidang Perikanan (first Edition) Rineka Cipta, Jakarta, 2011, P.12. 
Unregulated fishing is a fishing activity in the territorial waters or EEZ of a country that does not comply with the rules in force in that country; and (3) Unreported fishing, namely fishing activities in the territorial waters or EEZ of a country that are not reported both in terms of operations and vessel data and catches. ${ }^{2}$

The factors that cause Illegal Fishing in Indonesia are:

1. The need for global fish is increasing while the supply of fish is decreasing, thus encouraging fishing vessels to want to catch as many fishes as possible wherever legal or illegal;

2. The difference in price of whole fresh fish in other countries compared to Indonesia is quite high;

3. Fishing ground in other countries has run out while in Indonesia is still promising.

Fisheries criminal act is a prohibited act in all activities related to the management and utilization of fish resources and the environment starting from preproduction, production, management to marketing carried out in a fisheries business system, carried out by persons / legal entities capable of being responsible and threatened with criminal sanctions in accordance with Law Number 45 of 2009 concerning Amendment to Law Number 31 of 2004 concerning Fisheries. Therefore, the role of law enforcement is very important to overcome the violation of law in Indonesian waters.

2 Ketut Darmika, PENEGAKAN HUKUM TINDAK PIDANA PERIKANAN OLEH KAPAL PERANG REPUBLIK INDONESIA (KRI) DALAM PERSPEKTIF UNDANG-UNDANG RI NOMOR 45 TAHUN 2009 TENTANG PERIKANAN, Jurnal Hukum dan Peradilan, Volume 4, Nomor 3 November 2015, P. 485-500.
One form of law enforcement is to implement policies such as sinking foreign vessels that steal fish in Indonesian waters. ${ }^{3}$

According to data from FAO (2014), Indonesian marine fish catch is ranked second in the world with catches in 2012 of 5.40,247 tons. The first position as the largest capture fish producing country, namely China, was $13,869,604$ tons in 2012. ${ }^{4}$ Data from the Ministry of Maritime Affairs and Fisheries shows that the number of cases of fish theft that occurred in Indonesia in 2015 were 198 cases, in 2016 as many as 237 cases, and years 2017 as many as 193 cases.

The theft of fish resources in the Indonesian sea has caused huge losses to the fisheries sector in order to realize the welfare of the community. The Ministry of Maritime Affairs and Fisheries adopted a strict policy to eradicate illegal fishing through the act of sinking illegal fishing vessels. The magnitude of Indonesia's marine and fisheries wealth cannot be utilized optimally. Regarding these conditions, President Jokowi gave an evaluation as well as the following challenges: "70 percent two-thirds of Indonesia's territory is ocean. The potential is huge to become a driver of the national economy. The problem is, until now this potential has not been able to be utilized to the maximum by the community ".

3 Ibid.

4 Dewinta Ayu Syahrani, M. Al Musadieq, Ari Darmawan, ANALISIS PERAN KEBIJAKAN ILLEGAL, UNREPORTED, AND UNREGULATED FISHING (IUU) PADA EKSPOR IKAN TUNA DAN UDANG TANGKAP (Studi pada Sebelum dan Sesudah Penerapan Permen KP Nomor 56 dan 57/PERMENKP/2014 terhadap Volume Ekspor Tuna dan Udang Tangkap di Jawa Timur), Jurnal Administrasi Bisnis, Vol. 45 No.1 April 2017, P.27-36. 
Indonesia has not been able to become a maritime country because it has not been able to manage marine wealth and guarantee sea security. Abundant marine wealth has not been able to be used optimally for the progress of the nation's economy. Likewise related to maritime security, especially those bordering neighboring countries. The uncertainty of maritime boundaries and the occurrence of several cases related to national borders, make Indonesia have to work hard in developing maritime as a whole towards a resilient maritime country. The lack of partisanship to the maritime sector (maritime policy) is one of the reasons that has hampered the structuring of several infrastructures and has further increased the population of illegal fishing practices in Indonesian waters. ${ }^{5}$

The Ministry of Maritime Affairs and Fisheries as the main leading sector in the management and utilization of marine and fisheries wealth has taken a firm policy to eradicate illegal fisihing. One of the decisive actions is the sinking of foreign and ex-foreign vessels as concrete steps in the implementation of Law No. 45 of 2009 concerning Fisheries. The act of sinking a ship is a state action in eradicating illegal fishing activities and in addition to providing a deterrent effect and increasing the detterence effect of regional violations that can harm and threaten the country's sovereignty. Based on data released by the Directorate General of PSDKP KKP (2016) until February 2016, 153 fishing vessels have been sunk, for foreign

5 Mohammad Maulidan Kamal, PENEGAKAN HUKUM PENCURIAN IKAN DI WILAYAH ZONA EKONOMI EKSKLUSIF INDONESIA (ZEEI), JuristDiction: Vol. 1 No. 2, November 2018, P.609626. vessels including 20 fishing vessels from Malaysia, 43 from the Philippines, 1 from China, 21 from Thailand, 50 from Vietnam, 2 from Papua New Guinea, 1 from Belize, 1 Nigeria. ${ }^{6}$ However, according to the Indonesian traditional fishermen unit (KNTI) states, the sinking of ships in suppressing fish theft because until now there are still allegations of cases of illegal fishing. Because what happens is an increase in the number of ships sinking each year from 2015 by 113 ships, in 2016 by 115 ships, in 2017 it increased to 250 ships. $^{7}$

Illegal fishing is the biggest problem in the fishing industry in Indonesia and the effort to overcome this problem is very complicated because it involves many parties. Specifically to solve the problem of illegal fishing, Susi said she was ready to build three main pillars, namely making sovereignty the main key, sustainable management and promoting mutual prosperity. To uphold state sovereignty in the field of maritime affairs and fisheries, Susi placed the Directorate General of Maritime and Fisheries Resources Supervision and the Fish Quarantine and Quality Control Agency at the forefront. $^{8}$

6 Lilly Aprilya Pregiwati. (2019). Lagi, 13 Kapal Perikanan Asing Ilegal Ditenggelamkan di Natuna. Retrieved September 17, 2019, from Kementerian kelautan dan perikanan RI website: https://kkp.go.id/artikel/10594-lagi-13-kapalperikanan-asing-ilegal-ditenggelamkan-di-natuna

7 Rahman, M. (2018), Penenggelaman kapal ilegal tidak effetive tekan pencurian. Retrieved September 17, 2019, from 12 Januari 2018 website:

https://www.antaranews.com/berita/677207/pen enggelaman-kapal-ilegal-tidak-efektif-tekanpencurian-ikan

8 Fathiyah Wardah. (2018). Menteri Susi: Penenggelaman Kapal, Cara Tercepat Atasi Penangkapan Ikan Ilegal. Retrieved September 
Susi said that one of the causes of the fertility of illegal fishing in Indonesian waters was because in 2001 the government had allowed foreign ships to buy permits for fishing concessions in Indonesian waters. "That is what started massive and official illegal fishing in all parts of Indonesia. Because of what? They have official permits, official permits copied, one license, ten ships. See we have laws that we can actually execute and the right way in solve the problem in a short time, namely sinking the ship, "According to Susi, the burning and sinking of foreign vessels caught fishing illegally in Indonesia is not a new policy and this practice is regulated in Article 69 paragraph 4 of Law Number 45 of 2009 concerning Fisheries. ${ }^{9}$

The legal experts already know and understand what is the purpose of law namely:

1. Order is the closest destination;

2. Justice is the farthest destination and in the middle of both objectives;

3. Certainty;

4. Benefits.

However, in achieving these legal objectives, legal experts cannot ascertain whether the applicable law (law) has worked well in achieving these goals. Can a dispute solution or criminal charge lead to a court ruling establishing who the "winner" and "the losser" or peace between the parties, can be stated with certainty that the four legal objectives have been achieved or reflect the four legal objectives? the contribution of microeconomic analysis can help jurisprudents analyze current legal events and be able to predict with certainty and measurability about the legal political building in the future. The microeconomic analysis is also expected to overcome weaknesses or increase the strength that legal science has in carrying out its functions and roles to provide protection and guarantee legal certainty.

Referring to the movement and development of law and economics with the approach method, the knowledge of microeconomic analysis of the law is very relevant and important for legal science because legal analysis will acquire new knowledge, namely considering the "cost and benefit ratio" in the formation of laws and enforcement law, so the law does not work in a vacuum without any meaning and benefit for human life. Posner said, "economics is a powerful tool for analyzing a vast range of legal questions"; here economics means rational choice and price theory, combined with the assumption that 'resources tend to gravitate to their most valuable uses if voluntary exchange-market-is permitted"10

Becker specifically that the microeconomic analysis of criminal law includes:

1. Balance between certainty and severity of punishment;

2. An economic comparison between fines and imprisonment;

3. Economic aspects of law enforcement and procedural law;

4. The deterrence effect and prevention of imprisonment (including the death penalty).
17, 2019, from 01 Maret 2018

website:https://www.voaindonesia.com/a/susi-

penenggalaman-kapal-cara-tercepat-atasi-

penangkapan-ilegal-/4275490.html

9 Ibid.
10 Romli Atmasasmita dan Kodrat Wibowo, Analisis Ekonomi Mikro Tentang Hukum Pidana Indonesia, Kencana, Jakarta, 2016. P.20. 
In the New Order era, economists, economic agents, and authorities viewed the law as an obstacle to the continuity of economic activities. At that time, the law was not used as a basis, guide and activist in the economic field. The existence of law was undermined by the authorities only defending the New Order's economic politics which served the economic activities of developed countries and conglomerates and the Multi National Corporation (MNC). However, after the monetary crisis which devastated the economies of several countries in various parts of the world, they realized the importance of legal authority to create a conducive economic climate and to attract investment. ${ }^{11}$

Based on the explanation above, there is a question whether the sinking of ships in tackling the theft of fish in the territory of the Republic of Indonesia is in line with the principles of effective and efficient so that it reflects a maximizing and balanced punishment. In order to ensure the optimal and sustainable management of fish resources, it is necessary to increase the role of supervisors in the fisheries sector which is considered very important and quite strategic in order to support development in the fisheries sector in a controlled and in accordance with the principles of fisheries management, so that development can run in a sustainable (sustainable development) manner. the benefits can be felt for generations and across generations. ${ }^{12}$

11 Adi Sulistiyono dan Muhammad Rustamaji, Hukum Ekonomi Sebagai Panglima, Masmedia Buana Pustaka, Sidoarjo, 2009, P.17.

12 Osgar S. Matompo, PENANGANAN PRAKTIK PENCURIAN IKAN ILLEGAL DI PERAIRAN

\section{B. DISCUSSION}

1. Criminal Policy In Sinking Foreign Fishing Vessels In The Economic Analysis Perspective.

Most of the perpetrators of foreign fishermen have committed thefts of fish theft. The mode of theft of fish by foreign fishermen usually uses the Indonesian flag or using crew or crew from Indonesia. Violations have also been carried out by foreign investors or companies domiciled in Indonesia and supplying fish caught as a result of fish theft. The Minister of Maritime Affairs and Fisheries said that the number of illegal catches for all types of fish of a foreign vessel in Indonesian waters could reach 300 tons to 600 tons per year. This condition causes Indonesia to lose around US \$ 15 billion-US $\$ 25$ billion annually. ${ }^{13}$

International provisions that provide limitations on the subject of persons who commit violations in the waters of the EEZ are regulated in UNCLOS, which was ratified by Indonesia through Law Number 17 of 1985, concerning Ratification of the United Nations Convention on the Law of the Sea. The ratification of UNCLOS, brings logical consequences for Indonesia to carry out the mandate regarding rights and obligations in the management of marine areas based on international law. Implications for the ratification of

INDONESIA, Legality, Vol.26, No.1, Maret 2018-Agustus 2018, P. 130-141.

13 Hertria Maharani Putri, Radityo Pramoda, Maulana Firdaus, Law Perspective of Scuttling Policy for IUU Fishing in Indonesia, Jurnal Kebijakan Sosial ekonomi Kelautan dan Perikanan, Vol. 7 No. 2 Desember 2017, P.91102. 
UNCLOS 1982 require Indonesia to maintain the wealth of natural resources in the sea, as well as utilize it optimally for the national interests and for all the people of Indonesia. If an agreement has been made to a binding phase (ratification), the regulations that affect not only the provisions of international law (also relate to the fulfillment of the national legal provisions of a country). ${ }^{14}$

The sinking of illegal foreign fishing vessels (KIA) has been a contentious issue in the last few days. The Coordinating Minister for Maritime Affairs said that ship sinking was no longer necessary. On the other hand, many parties supported ship sinking to provide a deterrent effect for foreign fishermen perpetrators of illegal fishing. The sinking of illegal $\mathrm{MCH}$ has been regulated in Article 69 paragraph (4) of Law Number 45 Year 2009 concerning Amendment to Law 31 of 2004 concerning Fisheries, so that legally sinking a vessel is a legal action and does not need to be debated. In addition to the legality factor, there are a number of reasons both in terms of fisheries and operational techniques why sinking the ship needs to be done. ${ }^{15}$

It is in this matter of sovereignty and governmental authority that Indonesia can protect fishermen and natural

14 Ibid.

15 Yudhistira Rizky Abdillah. (n.d.). Mengapa Penenggelaman Kapal Perlu (Tetap) Dilakukan? Retrieved September 17, 2019, from Rabu 10 Januari 2018 website: https://news.detik.com/kolom/d3807932/mengapa-penenggelaman-kapalperlu-tetap-dilakukan resources owned at sea, enforce fish theft, violate fisheries, do not have licenses, violate territories and some other forms of law enforcement and sovereignty owned by Indonesia, It cannot be denied that the vast sea and islands of Indonesia are owned as gifts, gifts that must be managed and utilized as much as possible for the prosperity of the people, therefore the government is committed to jointly with other law enforcers directly under the Ministry of Maritime Affairs and Fisheries namely the TNI and Polri together in investigate, arrest and prosecute perpetrators of fish theft committed by foreign parties that automatically violate their sovereignty and violations of the fisheries Law such as not having SIUP and SIPI. ${ }^{16}$

Illegal, Unreported and Unregulated (IUU) Fishing is not only a problem experienced by Indonesia, but it is a global problem experienced by many countries. IUU Fishing results in overfishing and a decline in global fish stocks, which can threaten food security. Research shows that global losses from illegal fishing are estimated at around $\$ 10$ billion to $\$ 23$ billion. In addition, according to the 2015 WWF report, $86 \%$ of the total global capture fisheries stock is at risk from IUU Fishing activities. MCHs that do illegal fishing in Indonesia themselves mostly use destructive fishing equipment such as trawling so that

16 Tuah Kalti Takwa, PERANAN PERADILAN PERIKANAN DALAM KASUS PENCURIAN IKAN DI WILAYAH KEPULAUAN RIAU, JOM Fakultas Hukum, Volume II Nomor II Oktober 2015, P.1-15. 
it can damage the environment of fish resources. Therefore, it is a necessity for every country including Indonesia to protect its marine area from IUU Fishing activities in various ways.

Technically, patrol operations, one patrol boat has the ability to adhock or escort 5-6 fishing vessels, because officers need to be placed on the fishing boat to conduct escort. Meanwhile KIA perpetrators of illegal fishing usually gather in groups of dozens of ships, making it impossible to only capture 5 vessels and allow dozens of other vessels to drain our fish resources. In addition, the distance of EEZ which reaches 200 miles from the base line and the condition of the catching ship are also factors that must be considered. Instead of capturing only 5-6 ships which may be in poor condition and not possible to be brought to the port within hundreds of miles, it is better to immediately sink the dozens of KIA leaving some ships to immediately repatriate the crew to their home country. This method is more efficient and does not cause protests from the flag state because the $A B K$ who are their main concern immediately repatriated.

Based on the legal basis for fisheries, the act of sinking a vessel based on the provisions of Article 69 paragraph (1) and paragraph (4) of Law Number 45 of 2009 concerning Amendment to Law Number 31 of 2004 concerning Fisheries which reads:

a. The fishing supervisory vessel functions to carry out supervision and law enforcement in the field of fisheries in the territory of the Republic of Indonesia fisheries management;

b. Fishery control vessels as referred to in paragraph (1), can be equipped with firearms;

c. Fisheries control vessels can stop, inspect, carry and hold suspected or improper vessels suspected of committing violations in the territory of the Republic of Indonesia fisheries management to the nearest port for further processing;

d. In carrying out the functions as referred to in Paragraph (1) fisheries investigators and / or supervisors can take special measures in the form of burning and / or sinking of foreign-flagged fishing vessels based on sufficient preliminary evidence.

In carrying out the functions referred to in Paragraph (1) fisheries investigators and / or supervisors can take special measures in the form of arson and / or sinking of foreign-flagged fishing vessels based on sufficient preliminary evidence. The important thing to note regarding the sinking of this foreign ship is that it should not be carried out arbitrarily and must be based on sufficient preliminary evidence. "Sufficient preliminary evidence" means preliminary evidence for suspecting criminal offenses in the field of fisheries by foreign-flagged fishing vessels, for example foreign-flagged fishing vessels not possessing a Fishing License (SIPI) and a Fish Transport Vessel License (SIKPI), and obviously 
catch and / or transport fish when entering the territory of the Republic of Indonesia fisheries management. This provision shows that the special action cannot be carried out arbitrarily, but only if the fishery investigator and / or supervisor believes that the foreign-flagged fishing vessel is truly committing a criminal offense in the fishery sector.

The policy regarding the burning and / or sinking of foreignflagged fishing vessels based on Article 69 paragraph (4) of Law Number 45 of 2009 concerning Amendment to Law Number 31 of 2004 concerning Fisheries conducted by KRI seems to still cause juridical problems. On the one hand, there is still a debate over the authority of investigators in the act of sinking a foreignflagged fishing vessel, whether it is only done by a fishery control vessel. On the other hand, the sinking of foreign fishing vessels is related to the legal status of evidence of ships that have sunk as well as implications for the relationship between the Republic of Indonesia and related countries.

Criminal policy theory, criminal policy is an integral part of social policy (social policy) that is as an effort to provide protection to the community (social defense) and as an effort to achieve welfare (social welfare). So in addition to the need for an integral approach, the criminal also needs a holistic approach with several criteria as stated by Sudarto which consists of 4 criteria that must be considered and considered in determining criminalization, which mainly includes 2 things, first, the cost and benefit principle must be considered, meaning business to criminalize must be balanced with the results. Second, it must be considered whether criminalization adds to the burden of law enforcement officers so that it does not lead to overblasting so that the regulation is less effective. ${ }^{17}$

Becker specifically that the microeconomic analysis of criminal law includes:

a. Balance between certainty and severity of punishment;

b. An economic comparison between fines and imprisonment;

c. Economic aspects of law enforcement and procedural law;

d. The deterrence effect and prevention of imprisonment (including the death penalty).

The sinking policy of foreign fish-stealing vessels in Indonesian waters was pursued to secure the sea from looting by foreign parties. This policy will continue even though it could risk creating friction with the countries of origin of the foreign ship. The National Legal Development Agency, in its study relating to the evaluation of fisheries law states that the government needs to make a threat of punishment that provides a deterrent effect including the legitimacy of "burning and sinking fishing vessels both national and foreign fishing vessels in the waters of the islands, territorial sea and EEZ" for "Illegal Fishing "as an" ultimum remedium "with the

17 Teguh Prasetyo dan Abdul Halim Barkatullah, Politik Hukum Pidana Kajian Kebijakan Kriminalisasi dan Dekriminalisasi, Pustaka Pelajar, Yogyakarta 2005, P.12. 
requirement to make clear Operational Standards and Procedures (SOPs) regarding the implementation procedures so that they do not conflict with" human rights". Criminal sanctions in the Fisheries Act are formulated cumulatively except the formulation of violations in Article 97 and Article 100 which only formulates criminal fines. In cases which are categorized as other violations, namely Article 87 Paragraph (1) the criminal sanction is formulated as imprisonment for 2 (two) years and a fine of Rp. $1,000,000,000$. According to the author of this kind of punishment is inefficient and ineffective in tackling fish theft because the profits enjoyed by the perpetrators are greater than the fines contained in the formulation. And the imprisonment for 2 years is certainly not commensurate and has a deterrent effect, it is seen based on the increasing number of vessels that steal fish and which have been sunk based on what has been previously described. The sinking budget for the ship in 2015 was $\mathrm{Rp} 60$ billion. $^{18}$ When compared with the correctional operating costs, namely the cost of food for prisoners and detainees which amounts to an average of 100,000 people per year, with the unit price of BAMA (side dishes and rice) for one inmate on average per day is Rp. 15,000.- (five twelve

18 Yayu Agustini Rahayu. (2018). Menenggelamkan kapal butuh biaya yang tidak sedikit. Retrieved September 17, 2019, from Rabu, 10 Januari 2018 website:

https://www.merdeka.com/uang/kadinmenenggelamkan-kapal-butuh-biaya-yanq-idaksedikit.html thousand rupiahs), so that the total cost of BAMA from the APBN is $(100,000 \times$ Rp. 15,000) = Rp. $15,000,000,000$ (fifteen billion rupiahs). Of course the cost of sinking the ship is greater than the cost of correcting operational, but the punishing of prison is not effective and efficient both for the state and for the perpetrators of the crime of fish theft. Keeping operational costs of investigations to correctional institutions. As stated by Stephen J. Spur who compared imprisonment with fines and gave his opinion as follows: ${ }^{19}$

"One punishment that is widely used is imprisonment. The costs of this alternative include not only the cost to the prisioner of being miserable. But also the expense of building and operating prisons, and a loss of productivity of the offender during the period of incarceration. "The individuall will also less productive after his release. Because of his prolonged separation from the labor market and the stigma of conviction. Of a serious offense. The reduction of his productivity and earning capacity will lower the opportunity cost of crime, and increase likelihood that he will return to crime", (One of the most widely used sentences is a prison sentence. The cost of this alternative includes not only costs for prisoners to suffer in prison. But also costs for building and operating prisons, as well as loss of prisoner productivity during the detention period. "The prisoner is

19 Steven J Spurr, Economic Foundations of Law. Second Edition Routledge, (Economic Foundations of Law), New York, 2010, P.204. 
also less productive after their release, because they have been out of the labor market for a long time and are stigmatized by former criminals, reduced productivity and acceptance capacities will reduce the opportunity cost of returning to crime and clearly increase the likelihood that free prisoners will return to crime).

The author provides recommendations on the types of criminal offenses and the resolution of illegal fishing cases, namely in the form of criminal fines for legal subjects. Criminal fines can be used as an alternative punishment in addition to imprisonment in order to minimize operational costs of law enforcement. With regard to the opinion of Muladi and Barda Nawawi Arief, in establishing the legislature relating to the implementation of criminal fines, it is necessary to consider:

a. System for determining the amount or amount of criminal fines;

b. Deadline for the payment of fines;

c. Coercive measures that are expected to guarantee the payment of fines in the event that the convicted person cannot pay within the stipulated deadline;

d. Guidelines or criteria for imposing fines. ${ }^{20}$

Then it is necessary to imprison both prison and fines based on the category based on the type of offense and the consequences and threats of maximum and minimum as

20 Andi Hamzah, Terminologi Hukum Pidana, Sinar Grafika, Jakarta, 2009, P. 181 contained in the 2006/2007 draft RKUHP. Bearing in mind however, it is also necessary to consider, both imprisonment and fine penalties still stand on the view that, "man is a rational-actor-and immoral" that is able to make calculations about the advantages and disadvantages (cost and benefit analysis) of crimes that are (will) do. Criminal fines for their relationship with Pancasila have been accepted in the criminal justice system through the rigging of universal Pancasila principles. Penalty fines can fulfill the objectives of liberation, fostering towards a just and civilized society that is integrated in humanity and at the same time protecting the community in the Pancasila system. With the Pancasila-based economic approach so that criminal fines can become a state income that can be used in infrastructure development and other social insurance programs to achieve a prosperous society based on Pancasila as the philosophy of the Indonesian state.

The second recommendation is deprivation of when foreigners who steal in Indonesian territory are given to Indonesian fishermen who have an impact on increasing the income of fishermen and increasing the value of Indonesian fish exports which will certainly increase Indonesia's foreign exchange income. With the concept of the Pancasila approach which is the basis of the philosophy of the Indonesian State in the order of Indonesian law is a source of law because it is located as the basic norm of the state (staatsfundamentalnorm). That the 
law is a symptom in the reality of a pluralistic society, which has many aspects, dimensions and facets. Law is rooted and formed in the process of interaction of various societies (political, economic, social, cultural, technological, religious, etc.) formed and helped shape the social fabric, its shape is determined by the community with its various characteristics. But at the same time it also determines the form and nature of the community itself, so that in its dynamics the law is conditioned and conditions the community. Thus, based on the mandate in the GBHN that the target of the field of legal development is the establishment and functioning of a national legal system that is wellsourced to the Pancasila and the 1945 Constitution which is capable of ensuring certainty, order, enforcement and legal protection which is based on justice and truth and is capable and supporting national development. In this case, of course, in accordance with the objectives of the Indonesian state based on the Preamble of the 1945 Constitution which is to realize a just and prosperous Indonesian society.

\section{CONCLUSION}

Based on data released by the Directorate General of PSDKP KKP (2016) until February 2016, 153 fishing vessels have been sunk, for foreign vessels including 20 fishing vessels from Malaysia, 43 from the Philippines, 1 from China, 21 from Thailand, 50 from Vietnam, 2 from Papua New Guinea, 1 from Belize, 1 Nigeria. However, according to the Indonesian traditional fishermen unit (KNTI) states, the sinking of ships in suppressing fish theft because until now there are still allegations of cases of illegal fishing. Because what happens is an increase in the number of ships sinking each year from 2015 by 113 ships, in 2016 by 115 ships, in 2017 it increased to 250 ships. The policy regarding the burning and / or sinking of foreign-flagged fishing vessels based on Article 69 paragraph (4) of Law Number 45 of 2009 concerning Amendment to Law Number 31 of 2004 concerning Fisheries conducted by KRI seems to still cause juridical problems. On the one hand, there is still a debate over the authority of investigators in the act of sinking a foreign-flagged fishing vessel, whether it is only done by a fishery control vessel. On the other hand, the sinking of foreign fishing vessels is related to the legal status of evidence of ships that have sunk as well as implications for the relationship between the Republic of Indonesia and related countries. Criminal sanctions in the Fisheries Act are formulated cumulatively except the formulation of violations in Article 97 and Article 100 which only formulates criminal fines. In cases which are categorized as other violations, namely Article 87 Paragraph (1) the criminal sanction is formulated as imprisonment for 2 (two) years and a fine of Rp. 1,000,000,000. According to the author of this kind of punishment is inefficient and ineffective in tackling fish theft because the profits enjoyed by the perpetrators are greater than the fines contained in the formulation. And the imprisonment for 2 years is certainly not commensurate and has a deterrent effect, it is seen based on the increasing number of vessels that steal fish and which have been sunk based on what has been previously described. 


\section{BIBLIOGRAPHY}

\section{Book:}

Adi Sulistiyono dan Muhammad Rustamaji, 2009, Hukum Ekonomi Sebagai Panglima, Masmedia Buana Pustaka, Sidoarjo;

Andi Hamzah, 2009, Terminologi Hukum Pidana, Sinar Grafika, Jakarta;

Dewinta Ayu Syahrani, M. Al Musadieq, Ari Darmawan, ANALISIS PERAN KEBIJAKAN ILLEGAL, UNREPORTED, AND UNREGULATED FISHING (IUU) PADA EKSPOR IKAN TUNA DAN UDANG TANGKAP (Studi pada Sebelum dan Sesudah Penerapan Permen KP Nomor 56 dan 57/PERMENKP/2014 terhadap Volume Ekspor Tuna dan Udang Tangkap di Jawa Timur), Jurnal Administrasi Bisnis, Vol. 45 No.1 April 2017;

Hertria Maharani Putri, Radityo Pramoda, Maulana Firdaus, Law Perspective of Scuttling Policy for IUU Fishing in Indonesia, Jurnal Kebijakan Sosial ekonomi Kelautan dan Perikanan, Vol. 7 No. 2 Desember 2017;

Ketut Darmika, PENEGAKAN HUKUM TINDAK PIDANA PERIKANAN OLEH KAPAL PERANG REPUBLIK INDONESIA (KRI) DALAM PERSPEKTIF UNDANG-UNDANG RI NOMOR 45 TAHUN 2009 TENTANG PERIKANAN, Jurnal Hukum dan Peradilan, Volume 4, Nomor 3 November 2015;

Mohammad Maulidan Kamal, PENEGAKAN HUKUM PENCURIAN IKAN DI WILAYAH ZONA EKONOMI EKSKLUSIF INDONESIA (ZEEI), Jurist-Diction: Vol. 1 No. 2, November 2018;

Osgar S. Matompo, PENANGANAN PRAKTIK PENCURIAN IKAN ILLEGAL DI PERAIRAN INDONESIA, Legality, Vol.26, No.1, Maret 2018-Agustus 2018;

Romli Atmasasmita dan Kodrat Wibowo, 2016, Analisis Ekonomi Mikro Tentang Hukum Pidana Indonesia, Kencana, Jakarta;

Supramono, 2011, Hukum Acara Pidana dan Hukum Pidana di Bidang Perikanan (first Edition) Rineka Cipta, Jakarta;

Steven J Spurr, 2010, Economic Foundations of Law. Second Edition Routledge, (Economic Foundations of Law), New York;

Teguh Prasetyo dan Abdul Halim Barkatullah, 2005, Politik Hukum Pidana Kajian Kebijakan Kriminalisasi dan Dekriminalisasi, Pustaka Pelajar, Yogyakarta;

Tuah Kalti Takwa, PERANAN PERADILAN PERIKANAN DALAM KASUS PENCURIAN IKAN DI WILAYAH KEPULAUAN RIAU, JOM Fakultas Hukum, Volume II Nomor II Oktober 2015;

\section{Website:}

Fathiyah Wardah. (2018). Menteri Susi: Penenggelaman Kapal, Cara Tercepat Atasi Penangkapan Ikan Ilegal. Retrieved September 17, 2019, from 01 Maret 2018 website:https://www.voaindonesia.com/a/susi-penenggalam an-kapal-caratercepat-atasi-penangkapan-ilegal-/4275490. html

Lilly Aprilya Pregiwati. (2019). Lagi, 13 Kapal Perikanan Asing Ilegal Ditenggelamkan di Natuna. Retrieved September 17, 2019, from Kementerian kelautan dan perikanan RI website: https://kkp.go.id/artikel/10594-lagi-13-kapalperikanan-asing-ilegal-ditenggelamkan-di-natuna

Rahman, M. (2018), Penenggelaman kapal ilegal tidak effetive tekan pencurian. Retrieved September 17, 2019, from 12 Januari 2018 website: 
https://www.antaranews.com/berita/677207/ penenggelaman-kapal-ilegaltidak-efektif-tekan-pencurian-ikan

Yayu Agustini Rahayu, (2018). Menenggelamkan kapal butuh biaya yang tidak sedikit. Retrieved September 17, 2019, from Rabu, 10 Januari 2018 website: https://www.merdeka.com/uang/ kadin-menenggelamkan-kapal-butuh-biayayang-tidak-sedikit.html

Yudhistira Rizky Abdillah. (n.d.). Mengapa Penenggelaman Kapal Perlu (Tetap) Dilakukan? Retrieved September 17, 2019, from Rabu 10 Januari 2018 website: https://news.detik.com /kolom/d-3807932/mengapa-penenggelaman-kapalperlu-tetap-dilakukan 